\title{
The Role of Academic Libraries in Mentored Undergraduate Research: A Model of Engagement in the Academic Community
}

\section{Anthony Stamatoplos}

\begin{abstract}
Mentored undergraduate research is an emergent pedagogy in higher education. It differs fundamentally from course-related student research and is largely independent of the curriculum. Academic libraries should engage formally with the undergraduate research community. To do so, librarians will need to think and work beyond traditional models of library service, most notably in information literacy programs. The intent of this article is to raise awareness about opportunities for library involvement with undergraduate researchers and programs. Lessons from one university, including a formal partnership between a library and an undergraduate research center, suggest some general strategies that academic libraries might explore.
\end{abstract}

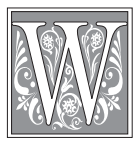

hen many librarians think of undergraduate student research, they likely picture the activities students engage in while working on papers and other assignments for courses. Many undergraduates, however, also engage in independent research. This includes a variety of activities through which students experience directly the work of a discipline under the guidance of a faculty research mentor. As an increasing number of students engage in such research, it has become the focus of many programs and professional organizations. In addition, it has received increasing coverage in the literature of various disciplines. In one nationwide survey of bachelor's degree recipients, about half of the respondents reported having participated in undergraduate research opportunities. ${ }^{1}$

Undergraduate research is emerging rapidly as a valued pedagogy in higher education. It has been described as "a comprehensive curricular innovation and major reform in contemporary American undergraduate education and scholarship." ${ }^{2}$ Because it is an experiential form of learning, campuses are recognizing undergraduate research as an important recruitment and retention tool. Undergraduate research is a growing part of student education and career development at institutions across the United States, and this has significant implications for academic libraries and librarians. 
It is important to understand the fundamental differences between traditional course-related student research and the kinds of experiences that are the focus of the undergraduate research movement. In typical course-related assignments, such as traditional term papers and various written and oral assignments, students acquire and communicate existing knowledge, generally without an expectation to produce original results or understanding. In that context, it is easy for librarians simply to equate student research with processes of information searching. In contrast, independent research experiences entail real hands-on experience in research conception, design, conduct, and dissemination and make inherent contributions to a discipline. Independent undergraduate research projects often derive from or relate to the scholarship of the faculty mentor and are expected to create new knowledge or creative scholarship as well as to be disseminated in a public forum. Thus, it has more in common with graduatelevel or faculty research than with the more familiar course-related activities of undergraduate students. Undergraduate research is, in effect, an apprenticeship. ${ }^{3}$ James M. Gentile's characterization of undergraduate research echoes what many faculty research mentors express: "research with undergraduate students is in itself the purest form of teaching."

There are obvious opportunities to extend existing library services, particularly information literacy programs, into the undergraduate research community. Librarians may be challenged in their own assumptions, understandings, and practices regarding students and faculty and may have to modify them. Once engaged, they may need to modify or broaden existing perspectives and might discover new roles to better fit this pedagogy.

The overall intent of this article is to raise the consciousness in the library literature and profession and to suggest some ways of thinking about and approaching mentored undergraduate research. It discusses undergraduate research and identifies emerging opportunities for library engagement with students and faculty involved in those activities. An example of collaboration at one institution illustrates some potential contributions and benefits to students, the university, and librarians. Drawing from those experiences, it suggests possible strategies for library engagement with independent undergraduate research.

\section{Undergraduate Research Defining Undergraduate Research}

A widely accepted definition of undergraduate research will help librarians differentiate it from more visible and familiar activities of students and faculty that focus primarily on learning through coursework and within the formal curriculum. The Council on Undergraduate Research (CUR) defines undergraduate research as "an inquiry or investigation conducted by an undergraduate student that makes an original, intellectual, or creative contribution to the discipline." 5 It combines teaching and research in ways such that "teaching and scholarship become parts of one simultaneous, overlapping, shared process." ${ }^{6}$ Ideally, the student learns through the research experience in more practical and lasting ways than he or she might through traditional classroom learning. The central premise of undergraduate research is "the formation of a collaborative enterprise between student and faculty member-most often one mentor and one burgeoning scholar but sometimes... a team of either or both."7 The faculty mentor "guides the novice researcher and initiates the student into the methods of a discipline." ${ }^{8}$

Mentored undergraduate research began in the sciences and has become increasingly common in a variety of fields. It occurs in the context of research programs and in one-to-one or team collaborations between faculty and students. Massachusetts Institute of Technology (MIT) started the first campuswide program in 1969, the Undergraduate Research Op- 
portunities Program (UROP). Since then, many institutions have developed their own UROPs, engaging several thousand students every year. In 1979, CALTECH instituted the Summer Undergraduate Research Fellowships (SURF) program, which has been adapted by several other institutions. Since the creation of those initial programs, many institutions have implemented undergraduate research activities and programs, which they either developed locally or adapted from others.

With the successes of these universitylevel programs, undergraduate research became recognized on a national level. CUR was formed in 1978, and it has become the foremost organization promoting undergraduate research. In the early 1980s, the National Science Foundation (NSF) began funding grants to support programs across the country through the Research Experiences for Undergraduates (REU) program. Since then, NSF, the National Institutes of Health (NIH), the U.S. Department of Education, and other federal agencies, as well as many private foundations, have established additional programs to fund this activity that connects faculty members and students to engage in independent research in both summer and academic year settings in colleges and universities. The National Conferences on Undergraduate Research (NCUR) was established in 1987 and supports the premier annual national conference for undergraduate researchers in all disciplines.

Undergraduate research addresses several of the goals of recent educational reform proposals. The 1998 Boyer Commission Report, for example, suggested 10 ways to change undergraduate education, the first being: "Make research-based learning the standard." ${ }^{\prime \prime}$ The report cites John Dewey's idea that "learning is based on discovery guided by mentoring rather than on the transmission of information." ${ }^{\prime 10}$ The Boyer Report contrasts inquiry-based learning with the traditional model in the university, expressing an ideal that would turn undergraduate culture from one of "receivers" to one of "inquirers," and to one in which faculty and students "share an adventure of discovery." 11 To do this, undergraduates must be involved in the research process and must be involved in mentoring relationships with instructors. ${ }^{12}$ This suggestion recognizes the value of undergraduate research as a vital pedagogy.

\section{Common Characteristics and Benefits of Undergraduate Research Experience}

The fundamental characteristics of undergraduate research discussed in the literature ${ }^{13}$ define it as real scholarship and together differentiate it from courserelated student research:

- Undergraduate research engages the student in inquiry-based and experiential learning. Students learn through practicing the methods of the discipline. Their research involves hands-on learning via the research process itself and application of knowledge and skills learned in the classroom.

- Faculty mentors guide and provide structure to students' research experiences. Student researchers are treated as members of the scholarly community, even if they are still novice members.

- Research is original. It creates new knowledge or understanding that contributes intellectually to the discipline. Student researchers disseminate results of their research to the scholarly community through oral or written communication or both.

- Students have primary responsibility for their projects, or some portion of them, and they take ownership of their work. Mentors encourage researchers to think and work independently, though they may collaborate on team projects with other students and faculty.

- Research is informed by, and builds upon, previous scholarship. Students become familiar with and appropriately use the literature of their disciplines and topics.

There are many anecdotal accounts in the literature of how this research 
approach benefits students, in addition to claims of benefits by programs and organizations. An increasing body of empirical evidence also gives weight to many of those claims. Several studies, for example, found intellectual gains associated with undergraduate research experience. ${ }^{14}$ Studies also have shown that students involved in undergraduate research gain self-confidence, ${ }^{15}$ are more likely to complete their degrees, ${ }^{16}$ and are more likely to go on to graduate school than students who did not have an undergraduate research experience. ${ }^{17}$ In an examination of undergraduate research experiences at four liberal arts institutions, Elaine Seymour et al. corroborated a variety of benefits reported in earlier anecdotal reports and smaller studies, as well as shed further light on many of those findings. Benefits fell into seven categories: (1) personal and professional gains; (2) "thinking and working like a scientist"; (3) gains in skills; (4) clarification, confirmation, and refinement of career/ education paths; (5) enhanced career/ graduate school preparation; (6) changes in attitudes toward learning and working as a researcher; and (7) other benefits. ${ }^{18}$ The Seymour et al. study also mentioned as specific areas of student improvement: communication and presentation skills, laboratory and field techniques, skills related to work and computers, and "information retrieval skills."19 Though gained through experience outside traditional coursework and curricula, such benefits relate to many of the desired outcomes of higher education. Indeed, some might argue that they could not be gained easily or as thoroughly through typical classroom or library research experiences.

\section{Looking for Undergraduate Research in the LIS Literature}

How do academic libraries engage undergraduate researchers and campus programs that support undergraduate research? How does the library and information science (LIS) literature represent mentored independent undergraduate research? An examination of the LIS literature reveals some noteworthy themes regarding student research. Fundamentally, there is a distinction between student and faculty research. Stephen K. Stoan, for example, compares scholarly research of faculty, which occurs in the context of a discipline, with the library use of undergraduate students, which by faculty standards is not research per se. ${ }^{20}$ Subsequent literature is consistent with that characterization. LIS literature does not distinguish essentially between variants of undergraduate research: for example, between course-related and course-independent activities. It conceptualizes undergraduate research exclusively in a context of course-related information seeking.

An extensive body of literature relates to the mechanics of student research, focusing both on behavior and thought processes, portraying research as seeking information to meet needs generated by a course. Many LIS authors focus on the information-finding behaviors of undergraduate students. One of the most influential authors in this regard is Carol C. Kuhlthau, who studied how high school and college students conduct research. Kuhlthau's model of the information search process (ISP) is cited frequently and is fundamental to many academic librarians' understanding of student research behavior. ${ }^{21}$ Several other authors ground their work in such studies as they seek to understand and explain research skills and behaviors of undergraduate students. ${ }^{22}$

Recent studies analyze citations in students' papers to infer patterns and processes they used in their research, adding another dimension to librarians' understanding. ${ }^{23}$ At least one such article implies faculty-mentored research as a basis for students' papers; however, the author did not deal with that aspect of the research. ${ }^{24}$ Numerous library use and user studies also add to the knowledge of how undergraduate students approach research and use information resources. 
Such studies continue the customary contextualization of undergraduate research within the formal curriculum. ${ }^{25}$ An extensive literature on information literacy overlaps with the literature of student information seeking and use. One sees in it the same conceptualization of undergraduate students' research as essentially course-driven. Information literacy practice, research, standards, and guidelines reflect this view. ${ }^{26}$

There is little evidence that LIS authors are cognizant of independent undergraduate research. At least, they do not identify it as such in their writing or treat it differently from course-related research. Rather, LIS literature effectively reduces the research of undergraduate students to processes of finding information and using information sources. Even when the term "undergraduate research" actually occurs in this literature, it generally denotes course-related informationseeking activities and processes. Based solely on the LIS literature, therefore, one would not know of the existence and nature of independent mentored undergraduate research or of examples of library engagement with it. Because the undergraduate research community is essentially absent or indistinguishable, this literature may not inform library engagement adequately. Librarians can only rely upon an available literature that presents undergraduate student researchers and their work in traditional ways with traditional assumptions.

\section{Importance of Formal Library Involvement to Undergraduate Researchers}

Faculty research descriptions, faculty publications, and the projects in which faculty members and undergraduate researchers collaborate imply considerable need for high-quality information and appropriate skills. Undergraduate research programs and evaluative studies frequently note the value of independent faculty-mentored research in learning the use of information skills and resources within a discipline. Explicit mention of libraries and information professionals, however, is virtually absent from the numerous accounts of research and programs. ${ }^{27}$ Information literacy seems to be either assumed or ignored. Ironically, students engaged in such activities may have greater and more complex overall need for quality information and evaluative skills than the average student engaged in course-related activities.

Because independent undergraduate researchers generally operate outside the formal curriculum, they can fail to recognize the potential value of interaction with librarians. Though many such researchers likely use libraries and librarians to some degree during their work, the information aspects of their work would certainly improve with greater understanding and formal attention by librarians. Also, faculty members may not instinctively refer their research protégés to libraries or librarians in the same way they might in a course environment. They may feel fully competent to manage their research students' information and library skills alone, while being themselves unaware of the assistance and value a librarian can bring to the collaborative research process and the student's knowledge of information resources. As for librarians, since such research is largely separate from coursework, it can be practically invisible because their focus is on supporting the formal curriculum. Therefore, they may exclude it from formal library services or programming and unintentionally neglect or underserve undergraduate researchers. Libraries may currently serve the undergraduate research community incidentally through existing services; however, this is too important an area not to consider and target it specifically when appropriate.

As undergraduate researchers are involved in the creation of new knowledge and understanding, their perspectives and approaches to information can differ from the familiar routine of ascertaining and describing existing knowledge, 
which may be only a part of the independent research experience. In a sense, people involved in original scholarship are different kinds of information users than those some librarians are used to and plan for, particularly where serving undergraduate students is a primary concern. The distinction between the nature of faculty and student research, discussed by Stoan and others, may no longer be as clear-cut. Undergraduate researchers generally have a more holistic view of their research experience and process and, presumably, of their information needs. The stakes are typically higher, and on the whole they seem more interested and thus more motivated in their information searching and in learning about and using resources than many users librarians normally encounter. Nevertheless, many undergraduate researchers may be no more likely to go beyond superficial interrogation of resources for their research projects than they might for a short paper for a course. Though their needs can in many ways resemble those of faculty researchers, such students understandably might not always think like experienced scholars. The librarian becomes a critical ally in the research process and a welcome guide to a more sophisticated approach to scholarship. The librarian can make a significant contribution to what is an inquiry-based model of teaching and learning both at the campus level and throughout the research community. Because librarians interact with students in developing transferable skills, knowledge, attitudes, and strategies when they assist them with their research, they affect student performance positively in other areas of their education.

Since the literature reveals no apparent examples or documented models of library engagement with undergraduate researchers and programs, only familiar models centered on engagement with students and faculty through the curriculum are available. It is not clear whether traditional assumptions and practices necessarily apply to mentored inde- pendent research. Generalized thinking about student research, such as Stoan's distinction between faculty and student research, may no longer fit the reality of research on college campuses today. Instead of the accepted dichotomy, librarians now might need to consider and address additional or hybrid varieties of research, or to understand academic research as existing on a continuum, regardless of who is conducting it. In addition, it would be prudent to study mentoring processes to gain some understanding of how teaching and learning differs in such environments. If library involvement in mentored undergraduate research is valuable, librarians need to share examples of successful practice and help develop appropriate models of engagement. They can begin by examining and learning from institutions in which there has been formal library engagement.

\section{Undergraduate Research on One Campus}

The history of undergraduate research activity at Indiana University-Purdue University Indianapolis (IUPUI) is typical among colleges and universities. There is a long tradition of student involvement in faculty research, particularly in the sciences and health-related disciplines. For many years, students have worked as laboratory assistants, data collectors, and so forth as they learned the skills and methods of their disciplines and became researchers themselves. In 1999 the university established its UROP. Like similar programs at other institutions, it provides money to encourage and support research, scholarship, and creative activities, as well as related travel. Every year, about 85 IUPUI students apply for and receive UROP funding for their research and research-related travel, creating significant opportunities for research and learning. The university also supports undergraduate research through other programs, such as a summer research program, supporting directly and indirectly an additional approximately 450 students. 
With the success of those programs, the UROP director conceptualized a campus center that would encourage, support, and increase mentored undergraduate research across disciplines and throughout the campus, while housing various research-related programs and activities. To accomplish this, the university established the Center for Research and Learning (CRL) in 2004. The CRL collaborates with other units and programs on campus as well as with individual faculty. Its board of directors is composed of members of the faculty and administration from across departments and includes two librarians. The CRL houses various undergraduate research programs and aims to develop additional programs and mechanisms of support. Programs currently housed within, administered by, or affiliated with the CRL include:

- the UROP

- the Diversity Scholars Research Program (DSRP)

- the Ronald E. McNair Scholars Program (a U.S. Department of Education TRiO Program)

- the NSF Alliance for Graduate Education and Professoriate (AGEP, through the Midwest Alliance Consortium with Indiana University)

- the Multidisciplinary Undergraduate Research Institute (MURI)

- the Louis Stokes Alliances for Minority Participation (LSAMP) program (supported by NSF)

- the Summer Research Opportunity Program (SROP).

As at other institutions, many students and mentors are active in independent undergraduate research outside these formal programs. The CRL seeks to identify and serve them as well.

Led by the CRL, the campus hosted and sponsored the 2004 NCUR conference. Approximately 2,400 students and faculty mentors from over 300 colleges and universities attended that conference, at which students presented their research in papers and posters. Beginning in 2006, the CRL also administered an NSF research grant.

\section{Library Collaboration with Undergraduate Research at IUPUI Early Librarian Involvement}

There has been a natural evolution of librarians' involvement with undergraduate research at IUPUI. It was not recognized specifically or formalized at first, but rather was undertaken in the context of traditional library services, such as reference, instruction, and relationships with assigned disciplines. The library recognized the potential benefits of more formal involvement and of collaboration with programs to create it. It already had engaged students and faculty successfully in other innovative pedagogies and programs such as instructional teams and learning communities, so it was well positioned and accustomed to taking on new areas.

A defining moment in the library's formal involvement with independent undergraduate research came during the conceptualization of the university's UROP. The program proposal was developed and coauthored by a four-person team that included a librarian. The invitation of library participation was a clear recognition of the value of information professionals by persons already active in this pedagogy and by upper administration. Since UROP's inception, the librarian on the development team has served as a member of the program's standing advisory committee, as a regular proposal reviewer, and has participated actively in many program-related activities and events.

Collaboration with UROP marked the beginning of the library's formal extension into undergraduate research activities. During that initial period, the librarian developed a better recognition of the nature of undergraduate research on campus and shared that perspective informally with colleagues. The relationship helped to position the library for future involvement and presented an opportunity to apply librarian perspectives and skills in a new place and in new ways. People associated with UROP 
quickly valued the library's involvement and resulting contributions, and there was a growing awareness of further opportunities for collaboration and potentially broader librarian roles in fostering undergraduate research.

Early in the library-UROP collaboration, there was a realization that students commonly think about and approach independent research differently from the way they think about and approach course-related research. Undergraduate researchers often had closer contact with faculty members in the mentoring environment than in the classroom environment, and their information use appeared to rely more on their mentors' ideas, suggestions, and sources. Though not as practiced as their mentors, undergraduate researchers seemed to seek and use information in ways similar to seasoned professional researchers. They appeared to be more independent in their information seeking and use of sources than students whose needs were dictated by courses. In this context, then, it should not be surprising that their patterns and use differed markedly from those that librarians have learned to expect from undergraduate students. Those students did not necessarily have frequent or formal contact with library personnel or resources in ways typical of students performing course-related research. Such realizations made it clear that there are ample opportunities for information professionals to apply their skills and knowledge in serving this community and much potential for continuing and expanding the involvement of the library.

\section{Library Collaboration with the Center for Research and Learning}

Another important milestone in the library's formal involvement with undergraduate research came during the university's planning of the CRL. Since its conception, the CRL envisioned librarians as essential to its work. This was evidenced by the fact that the initial proposal provided specifically for the eventual assignment of two librarians to support the CRL. Their experiences challenged some previous assumptions and practices regarding student and faculty work and research. Though they began work in a somewhat unfamiliar environment with different values and expectations, they have adapted to that culture and become comfortable working within it.

Independent student researchers share several basic needs with students doing course-related research. Like those students they sometimes need help understanding information systems, identifying specific needs, and devising effective search strategies and techniques. Much of the CRL librarians' work focuses on these more familiar activities and interactions with students and faculty mentors in the various undergraduate research programs. For example, they engage in individual consultation and both individual and group instruction in appropriate use of information resources.

Librarians have discovered that they must pay attention to the distinctive nature of undergraduate research and are learning to consider it in their interactions with undergraduate researchers and their mentors. In many ways, librarians have been able to engage students and faculty in ways that were unavailable previously and address some issues and problems they normally were unable to address in the course context. Because of the authentic nature of undergraduate research and relatively close relationships of students and faculty, librarians can have extensive and repeated engagement throughout the research experience and also can engage in more focused and meaningful ways. In addition to their many one-on-one interactions, librarians have been able to teach many workshops to student participants, all of whom were currently active in real research and presented real and urgent information needs. Those sessions contrast greatly with the more routine instruction sessions associated with classes. To serve students better, the CRL instituted a policy to include the contact information 
of the corresponding disciplinary librarian in the letter sent to each UROP grant recipient. When appropriate, CRL librarians also refer student researchers directly to other subject librarians for specialized assistance. Overall, CRL librarians are discovering more opportunities to have an effective presence in student and faculty work.

Librarians also contribute time and expertise to the CRL's work in less conventional ways. Within the CRL, librarians are regarded not as adjuncts but as faculty colleagues and senior staff members and, thus, an essential part of the organization. The librarians are integrated into the CRL in ways that go beyond typical liaison assignments to academic units. They have been involved in many planning and advisory activities and participate in various meetings of staff and other groups. They serve as reviewers and make recommendations for UROP grant proposals and for various undergraduate research awards programs on campus. Librarians participate in undergraduate research conferences and other public activities that often include reviewing abstracts, assisting in event planning, and facilitating conference and poster sessions. Both librarians serve on the CRL's board of directors and participate in that body's activities. Not only have these librarians participated in national conferences of CUR and NCUR, but they also were involved in planning the 2004 NCUR conference, including reviewing proposals for student papers and other various planning activities.

The library contributes funds as well as personnel to further the goals of the CRL. The library allocates money for materials to support the work of the CRL and contributes the costs of the acquisition, cataloging, and processing of those materials. The CRL librarian who manages those funds works with the CRL's director, staff, and fellow board members, as well as mentors, to identify and acquire appropriate materials. In 2006 the library further enhanced its support by initiat- ing an annual Undergraduate Research Award, given for "the best undergraduate project that specifically relies on the synthesis of library resources and collections, and the utilization of library services." This award includes a $\$ 500$ prize for the winning student. The award program was developed in large part by one of the CRL librarians. Another notable contribution of the library is the space in which the Center resides physically.

Librarians are making intellectual contributions through their work in the CRL. One librarian conducted an extensive literature review and created a research guide on mentorship of undergraduate research. Intended as a tool for the CRL, this was published subsequently as a peer-reviewed journal article. ${ }^{28}$ That librarian also coauthored two proposals for large research grants with faculty colleagues. The NSF funded one of those projects, ${ }^{29}$ and the librarian is a member of that research team. One librarian collaborated with the CRL director to give a presentation at a national conference. ${ }^{30}$ Similar scholarly and collaborative activities continue.

The partnership with the CRL is possible largely because of the library's overall response to change and the evolving needs of users. Because of this, its service model is in flux and services such as reference have changed in ways that afford more appropriate uses of personnel elsewhere. Besides its partnership with the CRL, the library collaborates with several nonlibrary entities on campus, such as the Center for Teaching and Learning (CTL), the learning communities programs, and the University Writing Center. Such partnerships would have been difficult to sustain within the more traditional service model and organizational structure of the past without either increasing library resources significantly or compromising service. As the reference desk becomes less central as the primary point of contact with users, the library has been able to reallocate full-time librarians' time in ways that permit more effective engagement through specialized one-on- 
one reference and research consultation, discipline-specific instruction, first-year learning community involvement, and development and support of an improved librarian Web presence in teaching and learning. In this way the library responds to the changing academic culture, making more immediate contributions in obvious pedagogy and adding value to structures outside the library.

The changing environment has had profound effects on trends in library services and on the roles and identity of academic libraries and librarians. ${ }^{31}$ There continues to be great concern in the literature about the direction and future of academic librarianship. ${ }^{32}$ In his model for transition of the academic library, David W. Lewis offers a five-part strategy that includes developing "partnerships with other campus units that support research, teaching, and learning." ${ }^{33}$ Similarly, he advocates that libraries "Reposition library and information tools, resources, and expertise so that they are embedded into the teaching, learning, and research enterprises," emphasizing "external, not library-centered, structures and systems." ${ }^{34}$ This essentially blurs "the boundaries that separate the library from the rest of the campus and the external information environment." 35 In Lewis's model, reference and library instruction change so that in-person interactions with faculty and students are enhanced and relationships with them strengthened. ${ }^{36}$ The IUPUI approach to library partnership with the CRL and other campus units is consistent with the strategy laid out by Lewis, in which he cites centers for teaching and learning and undergraduate research programs as examples of places to reposition librarians. ${ }^{37}$

The work of CRL librarians has entailed both contributing and learning, as well as involvement in a variety of capacities that are not normally seen as librarian work. This engagement is in a developing stage and librarians are exploring additional ways to involve their colleagues in supporting undergraduate research. It is vital that librarians meet the needs of academic communities they serve and of which they are a part, so they should investigate similar opportunities at their institutions and develop suitable approaches. There are several possible strategies for formal library engagement with undergraduate research, depending upon goals and structures of local programs and libraries. Lessons learned from the IUPUI experience may serve to inform other libraries in their engagement with undergraduate research programs. As a starting point, this model may show promise for other institutions to follow or adapt in their engagement.

\section{Some Recommended Strategies for Engagement \\ Develop Appropriate Awareness and Understanding}

Because mentored undergraduate research often is not immediately evident to them, librarians must make themselves aware of this pedagogy and its implications for their practice. They should become familiar with the literature of undergraduate research and the work of related professional organizations such as CUR and NCUR. They should pay particular attention to those organizations' Web sites ${ }^{38}$ and peruse the Council on Undergraduate Research Quarterly for examples of undergraduate research activities and concerns. Further, they should identify undergraduate research programs on their own campuses and cultivate relationships with faculty who administer and participate in them.

\section{Identify and Create Opportunities}

Informed by knowledge of undergraduate research pedagogy, and of activities and programs at their institutions, librarians must seek opportunities for formal involvement and collaboration. This may build upon existing strengths and skills, albeit in possibly new areas. Librarians should initiate relationships with faculty and programs, beginning by extending existing library services that may not adequately reach and serve this particular 
clientele. Libraries might focus first on delivering more informed and targeted services to student researchers and their mentors. They also must be amenable to adapting those existing services and strategies. One obvious opportunity is adapting services to assist reference staff in identifying and understanding the needs of researchers and mentors, thus better serving them through reference, consultation, and referral services. Libraries also can extend and adapt information literacy programs to include undergraduate research activities and needs, which will have several benefits and help further integrate information literacy into the academic culture. Indeed, this would be in accordance with ACRL's "Guidelines for Instruction Programs in Academic Libraries," which mentions (albeit cursorily) undergraduate research as a program structure with which instruction programs can become engaged. ${ }^{39}$

\section{Focus on Student-Mentor Relationships}

The most critical objective of librarian involvement may be to apply perspectives and skills of information professionals to develop methods of supporting and enhancing student-mentor relationships. Just as librarians have worked to integrate information literacy into the curriculum, they must devise ways to infuse their presence into both the research and teaching aspects of these relationships. It is imperative that librarians understand the dynamics of mentoring and find ways to support and enhance those relationships. A principal goal should be to strengthen and influence the information aspects of mentoring. For example, librarians should understand how mentors address literature reviewing and information retrieval as part of research and seek ways to support and influence such processes. They need to better equip mentors and make themselves available to them and their students for consultation and instruction in various settings. Overall, librarians' goals should include helping students become more effective information users, helping mentors become more effective teachers, and helping the library become more effective and better integrated in the life of the undergraduate research community.

\section{Develop New Frameworks for Working with Students and Faculty}

Bearing in mind that the work and programs of undergraduate research exist largely outside the curriculum, librarians need to find suitable ways to engage students involved in relatively unique projects in authentic settings. Librarians need to support these students' essential needs to acquire and build upon previous scholarship, to help them to work effectively in such contexts and add to the body of scholarship. Once librarians engage formally, they will develop more specific understandings of the work and needs of researchers and mentors and be able to identify ways to meet them on their terms to serve that community better. Considering the nature of undergraduate research, librarians must be willing to modify their approaches to service and develop new and creative strategies when necessary. They should work to understand and support research mentorship to the same degree and with the same enthusiasm they bring to course-based teaching and learning. As libraries work to integrate information literacy into the curriculum, they should broaden such efforts to include undergraduate research and other experiential learning pedagogies.

\section{Make Strong and Explicit Commitments}

Libraries must develop formal commitments to and relationships with undergraduate research programs that are analogous to their support of teaching and learning within the curriculum. These should occur both at the administrative level and with individual librarians. Library administration must promote and encourage staff and organizational involvement in undergraduate research activities and demonstrate their importance in tangible ways. Administrators must communicate and partner with 
program administrators and show their own commitment through their presence at and participation in events and activities. They should demonstrate genuine support through allocation of financial and human resources. For example, they could assign personnel and contribute money for collections and space for activities and events. They should identify librarians who have relevant experience and expertise, as well as existing involvement and relationships with undergraduate research. They should build on these and formalize them when possible by adjusting organizational structures and making formal personnel assignments that are made clear in position descriptions. Administrators and organizations must accept librarians' involvement with undergraduate research as equal to engagement with students and faculty in more familiar ways. Further, administrators should allow and encourage librarians' experimentation and development of new practices and collaborative relationships. Administration should promote scholarly collaboration between library personnel and mentors and program administrators in research, publication, and participation in conferences and programs.

\section{Conclusion}

Excellent library service begins with understanding the community and positioning the library to be where users are when library services and information resources are needed. This implies a willingness to meet the community on their terms and to close service gaps that might exist. Undergraduate research presents additional opportunities to accomplish this in academic communities. A key to this kind of engagement will be a proper understanding of users and a regard for what makes sense and may really be needed, rather than blindly imposing processes, systems, and programs. In recent years, academic libraries have sought partnerships with other campus entities and programs involved in teaching and learning. Some libraries have developed relationships working in learning communities or other powerful pedagogies. Those partnerships opened new roles and responsibilities for librarians and challenged traditional views about the place of the library in the institution. Undergraduate research holds similar opportunities.

Working with undergraduate researchers can be enjoyable and motivating for librarians. In a time when many academic libraries experience less in-person interaction with users, involvement with the undergraduate research community provides another viable opportunity to make a difference in the academic lives of students and faculty. Many academic librarians yearn for more in-depth and meaningful engagement with students and faculty. Because of the nature of undergraduate research, it can provide librarians such opportunities and give them a more direct sense of success and impact on teaching, learning, and research. Similarly, libraries can explore analogous opportunities and models of engagement with other experiential learning enterprises, such as service learning, internships, and study abroad.

Undergraduate research presents opportunities for librarians to extend their reach on campus and engage a larger number and broader range of students, faculty, and disciplines. This requires collaborative relationships in which librarians are partners with faculty and students. In such collaboration, librarians must be open to new and creative strategies for contributing to education and scholarship. The result should be not only greater involvement but also greater impact in the academic community. This model of engagement has the potential of helping build crucial connections in which the library plays a vital and valued role with visible impact. Productive engagement in undergraduate research can become a significant example of the enduring relevance of academic librarianship. 


\section{Notes}

1. Susan H. Russell, Mary P. Hancock, and James McCullough, "Benefits of Undergraduate Research Experiences," Science 316, no. 5824 (Apr. 27, 2007): 548-49.

2. National Conferences on Undergraduate Research, Joint Statement of Principles in Support of Undergraduate Research, Scholarship, and Creative Activities. Available online at www.ncur.org/ ugresearch.htm. [Accessed 30 August 2008].

3. For a discussion of undergraduate research experiences as cognitive apprenticeships, see CarolAnne M. Kardash, "Evaluation of an Undergraduate Research Experience: Perceptions of Undergraduate Interns and their Faculty Mentors," Journal of Educational Psychology 92, no. 1 (Mar. 2000): 191-201.

4. James M. Gentile, "Then and Now: A Brief View of Hope College Today," in Academic Excellence: The Role of Research in the Physical Sciences at Undergraduate Institutions, ed. Michael P. Doyle (Tucson, Ariz.: Research Corporation, 2000): 79-85.

5. Council on Undergraduate Research, About CUR. Available online at www.cur.org/about. html. [Accessed 30 August 2008].

6. National Conferences on Undergraduate Research, Joint Statement of Principles.

7. Ibid.

8. Joyce Kinkead, "Learning through Inquiry: An Overview of Undergraduate Research," in Valuing and Supporting Undergraduate Research, ed. Joyce Kinkead (San Francisco, Calif.: JosseyBass Publishers, 2003), 5-17.

9. Boyer Commission on Educating Undergraduates in the Research University, Reinventing Undergraduate Education: A Blueprint for America's Research Universities (Stony Brook, N.Y.: State University of New York, 1998).

10. Ibid.,15.

11. Ibid.,16.

12. Ibid.,17-18.

13. National Conferences on Undergraduate Research, Joint Statement of Principles ; David Lopatto, "The Essential Features of Undergraduate Research," Council on Undergraduate Research Quarterly 23, no. 3 (Mar. 2003): 139-42; Martha H. Bowman and Frances K. Stage, "Personalizing the Goals of Undergraduate Research: Implementing Three Types of Goals," Journal of College Science Teaching 32, no. 2 (Oct. 2002): 120-25; Joyce Kinkead, "Learning through Inquiry," 5-17.

14. Toufic Hakim, "Soft Assessment of Undergraduate Research: Reactions and Student Perspectives," Council on Under graduate Research Quarterly 18, no. 4 (June 1998): 189-92; Kardash, "Evaluation of an Undergraduate Research Experience," 191-201; Russell S. Hathaway, Biren A. Nagda, and Sandra R. Gregerman, "The Relationship of Undergraduate Research Participation to Graduate and Professional Education Pursuit: An Empirical Study," Journal of College Student Development 43, no. 5 (Sept./Oct. 2002): 614-31; John Ishiyama, "Does Early Participation in Undergraduate Research Benefit Social Science and Humanities Students?" College Student Journal 36, no. 3 (Sept. 2002): 380-87; David Lopatto, "Survey of Undergraduate Research Experiences (SURE): First Findings," Cell Biology Education 3, no. 4 (Winter 2004): 270-77; Elaine Seymour, Anne-Barrie Hunter, Sandra L. Laursen, and Tracee Deantoni, "Establishing the Benefits of Research Experiences for Undergraduates in the Sciences: First Findings from a Three-Year Study," Science Education 88, no. 4 (July 2004): 493-534; Russell, Hancock, and McCullough, "Benefits of Undergraduate Research Experiences," 548-49.

15. Joseph R. Ferrari and Leonard A. Jason, "Integrating Research and Community Service: Incorporating Research Skills into Service Learning Experiences," College Student Journal 30, no. 4 (Dec. 1996): 444-51; Ashley J. Campbell and Gerald D. Skoog, "Preparing Undergraduate Women for Science Careers: Facilitating Success in Professional Research," The Journal of College Science Teaching 33, no. 5 (Mar./Apr. 2004): 24-26; Seymour, Hunter, Laursen, and Deantoni, "Establishing the Benefits of Research Experiences," 493-534; Russell, Hancock, and McCullough, "Benefits of Undergraduate Research Experiences," 548-49.

16. Biren A. Nagda, Sandra R. Gregerman, John Jonides, William von Hippel, and Jennifer S. Lerner, "Undergraduate Student-Faculty Research Partnerships Affect Student Retention," Review of Higher Education 22, no. 1 (Fall 1998): 55-72; John Ishiyama, "Undergraduate Research and the Success of First Generation, Low Income College Students," Council on Under graduate Research Quarterly 22, no. 1 (Sept. 2001): 36-41.

17. John F. Kremer and Robert G. Bringle, "The Effects of an Intensive Research Experience on the Careers of Talented Undergraduates," Journal of Research and Development in Education 24, no.1 (Fall 1990): 1-5; Usha Chandra, Sara Stoecklin, and Marion Harmon, "A Successful Model for Introducing Research in an Undergraduate Program," Journal of College Science Teaching 28, no. 2 (Nov. 1998): 113-18; Ishiyama, "Undergraduate Research and the Success of First Generation, 
Low Income College Students," 36-41; Karen W. Bauer and Joan S. Bennett, "Alumni Perceptions Used to Assess Undergraduate Research Experience," The Journal of Higher Education 74, no. 2 (Mar./Apr. 2003): 210-30; Russell, Hancock, and McCullough, "Benefits of Undergraduate Research Experiences," 548-49.

18. Seymour, Hunter, Laursen, and Deantoni, "Establishing the Benefits of Research Experiences," 493-534.

19. Ibid.,518-19.

20. Stephen K. Stoan, "Research and Library Skills: An Analysis and Interpretation," College $\mathcal{E}$ Research Libraries 45, no. 2 (Mar. 1984): 99-109.

21. Carol C. Kuhlthau, "Developing a Model of the Library Search Process: Cognitive and Affective Aspects," RQ 28, no. 2 (Winter 1988): 232-42; Carol C. Kuhlthau, "Inside the Search Process: Information Seeking from the User's Perspective," Journal of the American Society for Information Science 42, no. 5 (June 1991): 361-71.

22. Barbara Fister, "The Research Processes of Undergraduate Students," The Journal of Academic Librarianship 18, no. 3 (July 1992): 163-69; Barbara Valentine, "Undergraduate Research Behavior: Using Focus Groups to Generate Theory," The Journal of Academic Librarianship 19, no. 5 (Nov. 1993): 300-304; Barbara Valentine, "The Legitimate Effort in Research Papers: Student Commitment versus Faculty Expectations," The Journal of Academic Librarianship 27, no. 2 (Mar. 2001): 107-115; Gloria J. Leickie, "Desperately Seeking Citations: Uncovering Faculty Assumptions about the Undergraduate Research Process," The Journal of Academic Librarianship 22, no. 3 (May 1996): 201-08; Ethelene Whitmire, "A Longitudinal Study of Undergraduates' Academic Library Experience," The Journal of Academic Librarianship 27, no. 5 (Sept. 2001): 379-85; Ethelene Whitmire, "Disciplinary Differences and Undergraduates' Information-Seeking Behavior," Journal of the American Society for Information Science and Technology 53, no. 8 (June 2002): 631-38.

23. Joseph R. Kraus, "Citation Patterns of Advanced Undergraduate Students in Biology, 2000-2002," Science \& Technology Libraries 22, no. 3/4 (2002): 161-79; Reba Leiding, "Using Citation Checking of Undergraduate Honors Thesis Bibliographies to Evaluate Library Collections," College $\mathcal{E}$ Research Libraries 66, no. 5 (Sept. 2005): 417-29; Jake Carlson, "An Examination of Undergraduate Student Citation Behavior," The Journal of Aademic Librarianship32, no. 1 (Jan. 2006): 14-22; Leslie Kriebel and Leslie Lampham, "Transition to Electronic Resources in Undergraduate Social Science Research: A Study of Honors Theses Bibliographies, 1999-2005," College E Research Libraries 69, no. 3 (May 2008): 268-83.

24. Kraus, "Citation Patterns of Advanced Undergraduate Students in Biology, 2000-2002."

25. See, for example, George D. Kuh and Robert M. Gonyea, "The Role of the Academic Library in Promoting Student Engagement in Learning," College E Research Libraries 64, no. 4 (July 2003): 256-82; Studying Students: The Undergraduate Research Project at the University of Rochester, ed. Nancy F. Foster and Susan Gibbons (Chicago: Association of College and Research Libraries, 2007).

26. See, for example, Hannelore B. Rader, "Information Literacy 1973-2002: A Selected Literature Review," Library Trends 51, no. 2 (Fall 2002): 242-59; Gregory A. Crawford and Jessica Feldt, "An Analysis of the Literature on Instruction in Academic Libraries," Reference E User Services Quarterly 46, no. 3 (Spring 2007): 77-88; Association of College and Research Libraries, "Information Literacy Competency Standards for Higher Education," September 1, 2006, available online at www.ala.org/ala/acrl/acrlstandards/informationliteracycompetency.cfm (accessed 30 August 2008); Association of College and Research Libraries, “Objectives for Information Literacy Instruction: A Model Statement for Academic Librarians," September 1, 2006, available online at www. ala.org/acrl/acrlstandards/objectivesinformation.cfm (accessed 30 August 2008); Association of College and Research Libraries, "Guidelines for Instruction Programs in Academic Libraries," September 6, 2006, available online at www.ala.org/acrl/acrlstandards/guidelinesinstruction. cfm (accessed 30 August 2008); Association of College and Research Libraries, "Guidelines for University Library Services to Undergraduate Students," September 1, 2006, available online at www.ala.org/ala/acrl/acrlstandards/ulsundergraduate.cfm (accessed 30 August 2008).

27. For an example of an exception, see Bowman and Stage, "Personalizing the Goals of Undergraduate Research," 122-23.

28. Anthony Stamatoplos, "An Annotated Bibliography of Faculty Mentoring of Undergraduate Research," Council on Undergraduate Research Quarterly 26, no. 2 (Dec. 2005): 84-89.

29. Kathryn J. Wilson, Mary Crowe, Sharon J. Hamilton, and Anthony C. Stamatoplos, "Using Electronic Portfolios to Assess Student Learning as a Result of Undergraduate Research" (National Science Foundation CCLI Grant \#0618617, 2006-2009).

30. Kathryn J. Wilson and Edward L.F. González, "The Benefits of Integrating Faculty Librarians with Campus Funded Undergraduate and Graduate Research Programs." Paper presented at the 21st National Conference on Undergraduate Research (NCUR), San Rafael, Calif., Apr. 12-14, 2007. 
31. For recent discussions of trends in academic library use, see Charles Martell, "The Elusive User: Changing Use Patterns in Academic Libraries 1995 to 2004," College E Research Libraries 68, no. 5 (Sept. 2007): 435-44; Christen Cardina and Donald Wicks, "The Changing Roles of Academic Reference Librarians Over a Ten-Year Period," Reference E User Services Quarterly44, no. 2 (Winter 2004): 133-42; American Library Association, "Changing Roles of Academic and Research Libraries," Apr. 18, 2007, available online at www.ala.org/ala/acrl/acrlissues/future/changingroles.cfm (accessed 30 August 2008); Lyman Ross and Pongracz Sennyey, "The Library is Dead, Long Live the Library! The Practice of Academic Librarianship and the Digital Revolution," The Journal of Academic Librarianship 34, no. 2 (Mar. 2008): 145-52.

32. Gregg Sapp and Ron Gilmour, "A Brief History of the Future of Academic Libraries: Predictions and Speculations from the Literature of the Profession, 1975-2000 - part one, 1975-1989," portal: Libraries and the Academy 2, no, 4 (Oct. 2002): 553-76; Gregg Sapp and Ron Gilmour, "A Brief History of the Future of Academic Libraries: Predictions and Speculations from the Literature of the Profession, 1975-2000-part two, 1990-2000," portal: Libraries and the Academy 2, no, 4 (Jan. 2003): 13-34; James L. Mullins, Frank R. Allen, and Jon R. Hufford, “Top Ten Assumptions for the Future of Academic Libraries and Librarians: A Report from the ACRL Research Committee," CERL News 68, no. 4 (Apr. 2007): 240-41, 246; Bill Crowley, Renewing Professional Librarianship: A Fundamental Rethinking (Westport, Conn.: Libraries Unlimited, 2008).

33. David W. Lewis, "A Strategy for Academic Libraries in the First Quarter of the 21st Century," College E Research Libraries 68, no. 5 (Sept. 2007): 420.

34. Ibid., 420 .

35. Ibid., 428 .

36. Ibid., 425 .

37. Ibid., 425 .

38. Council on Undergraduate Research, "CUR-Council on Undergraduate Research," available online at www.cur.org (accessed 30 August 2008); National Conferences on Undergraduate Research, "National Conferences on Undergraduate Research," available online at www.ncur. org (accessed 30 August 2008).

39. Association of College and Research Libraries, "Guidelines for Instruction Programs in Academic Libraries."

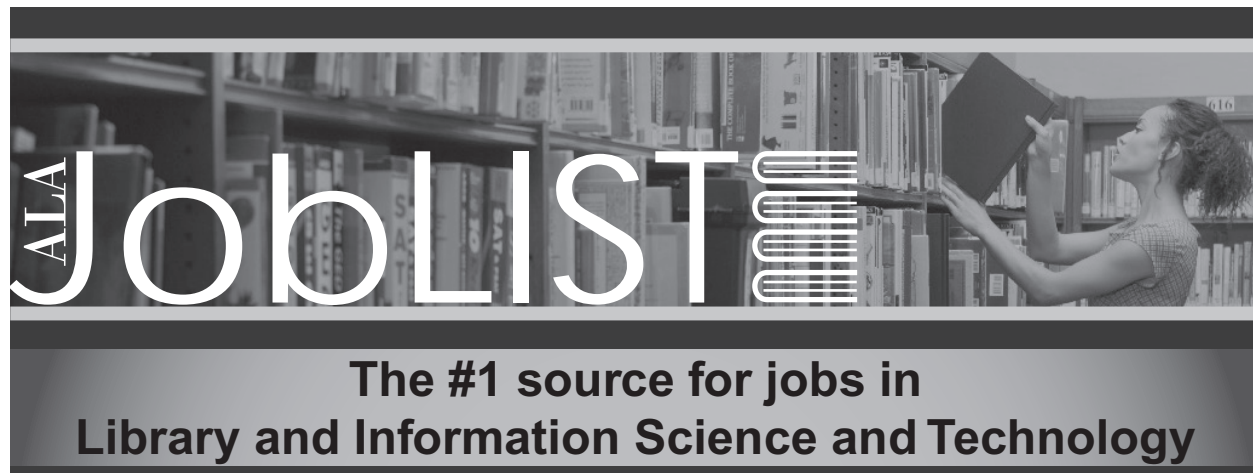

\section{Job Seekers}

- Search hundreds of job ads by employer, library type, location, salary range, and more

\section{Employers}

- Strengthen your candidate pool by reaching the profession's most engaged members

\section{One Web site. Far-reaching results. http://JobLIST.ala.org}

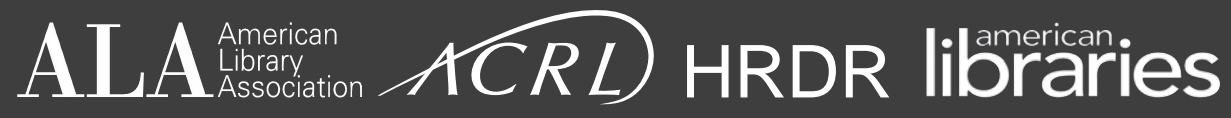

